\title{
Precipitation and Dissolution of Calcite in a Swiss High Alpine Lake*
}

\section{Christian Ohlendorf and}

\section{Michael Sturm}

Swiss Federal Institute of

Environmental Science and

Technology (EAWAG), Überlandstr.

133, CH-8600 Dübendorf,

Switzerland.

ohlendorf@eawag.ch,

sturm@eawag.ch

\begin{abstract}
Water chemistry and sediment trap data from the 18.9-m-deep, high-altitude, hardwater lake Hagelseewli ( $2339 \mathrm{~m}$ asl.) indicates that biogenic induced calcite precipitation occurs in a water depth of 6 to $9 \mathrm{~m}$ at a temperature of $4^{\circ} \mathrm{C}$. Our data indicates that calcite precipitation takes place as a short pulse that lasts less than $14 \mathrm{~d}$ in response to photosynthetic $\mathrm{CO}_{2}$ uptake in late summer probably by cyanobacterial picoplankton. In up to 8.4 times supersaturated water $30 \mu \mathrm{m}$ large calcite crystals precipitate that show surface features typical for eutrophic lakes (rough surface and enhanced columnar growth). Subsequently, during the long period of ice coverage calcite is completely dissolved in strongly undersaturated bottom waters. Sediment calcite concentrations therefore are below $0.3 \%$, although the comparison of trap fluxes and sediment accumulation rates indicates that they could be as high as $25 \%$. The theoretical annual accumulation of calcite in Hagelseewli is similar in magnitude to a single spring precipitation event in a low-altitude temperate, hardwater lake. In the most recent sediments the occurrence of higher amounts of organic carbon and sulfur indicates increasing bottom water anoxia during the last 30 to $40 \mathrm{yr}$.
\end{abstract}

\section{Introduction}

Biogenically induced inorganic calcite precipitation in freshwater lakes is a well studied phenomenon (Minder, 1922; Brunskill, 1969; Kelts and Hsü, 1978; Stabel, 1986; and many others). It can be recognized for example, as "whitings" in most hardwater lakes all over the world (Müller, 1966; Strong and Eadie, 1978; Hodell et al., 1998). In low salinity, thermally stratified lakes of various sizes, it is usually associated with high water temperatures and high productivity in the epilimnion. A water temperature increase reduces the solubility of $\mathrm{CaCO}_{3}$ both directly and indirectly through its influence on primary production rates. It is therefore viewed as the most important factor controlling calcite precipitation in a lake (Hodell et al., 1998). Calcite crystals form in highly supersaturated waters usually by heterogenous nucleation (Kunz and Stumm, 1984). Precipitation of up to $60 \mu \mathrm{m}$, large crystals can occur very rapidly (Sturm et al., 1997) and in pulses that quickly reach the lake bottom with sinking velocities of 1.5 to $6.0 \mathrm{~m} \mathrm{~h}^{-1}$ (Sturm et al., 1982). To our knowledge authigenic calcite formation has never been reported from another cold $\left(4^{\circ} \mathrm{C}\right)$ hardwater, high-altitude lake.

In the framework of the international project Mountain Lake Research (MOLAR) we combined water chemsitry analysis with a sediment trap and core study in the Swiss high-altitude lake Hagelseewli (2339 $\mathrm{m}$ a.s.l.) in order to gain new insights in freshwater carbonate cycling. In this paper we demonstate that calcite precipitation events in this lake are in the same order of magnitude as in low-altitude temperate lakes but occur under fundamentally different physical boundary conditions and are not archived in the sedimentary record.

*A version of this paper was presented at the symposium "Highmountain Lakes and Streams: Indicators of a Changing World," 4 8 September 2000, Innsbruck, Austria.

\section{Site Characterization}

In the Bernese Alps of Switzerland at an altitude of 2339 m a.s.l., the small (surface area: $24,000 \mathrm{~m}^{2}$ ) but relatively deep $(18.5 \mathrm{~m})$ Hagelseewli $\left(46^{\circ} 40^{\prime} \mathrm{N}, 8^{\circ} 02^{\prime} \mathrm{E}\right)$ is located in a northfacing cirque (Fig. 1, for more details see Lotter et al., 2000). Its small catchment $\left(0.3 \mathrm{~km}^{2}\right)$ is dominated by a high cliff face to the south (Fig. 1), whereas the area to the north is relatively flat. The lake has a small outflow to the north but only a minor inflow at the western shore. Water supply mainly takes place by diffuse flows from the cliff face and from the surrounding flatter land.

Geologically, Hagelseewli is situated in middle Jurassic (Bajocien/Callovien) sedimentary rocks of a Helvetic alpine nappe (for details see Ohlendorf at al., 2000). The cliff to the south (Fig. 1) consists of clayey, schistose, brittle marls interbedded with fine-grained siliceous limestones (thickness: 20-30 $\mathrm{cm}$ ). The two units have a $\mathrm{CaCO}_{3}$-content of 14 and $40 \%$, respectively. The cliff is covered with talus deposits that are probably stabilized by perennial permafrost.

Due to its high altitude, air temperatures at Hagelseewli are generally low. Monthly mean temperatures lie below $0^{\circ} \mathrm{C}$ during about 6 months of the year. Moreover, on-site meteorological measurements revealed that local topographic shading by the high cliff diminishes incident solar radiation by 15 to $90 \%$ (Livingstone et al., 1999; Goudsmit et al., 2000; Ohlendorf et al., 2000). Accordingly lake surface water temperatures are unusually low even for this altitude and the period of ice coverage is extremely long. Water temperatures increase above $1^{\circ} \mathrm{C}$ only during 4 to 5 months a year. During long, hot summers surface water may warm up to $10^{\circ} \mathrm{C}$, whereas during cooler summers (e.g., 1987) the ice cover may not even thaw completely (Lotter et al., 2000). Hence, productivity and biogeochemical cycling in Hagelseewli mainly are controlled by the status of ice-cover and thus indirectly by local climate (or more precisely local radiation balance). 


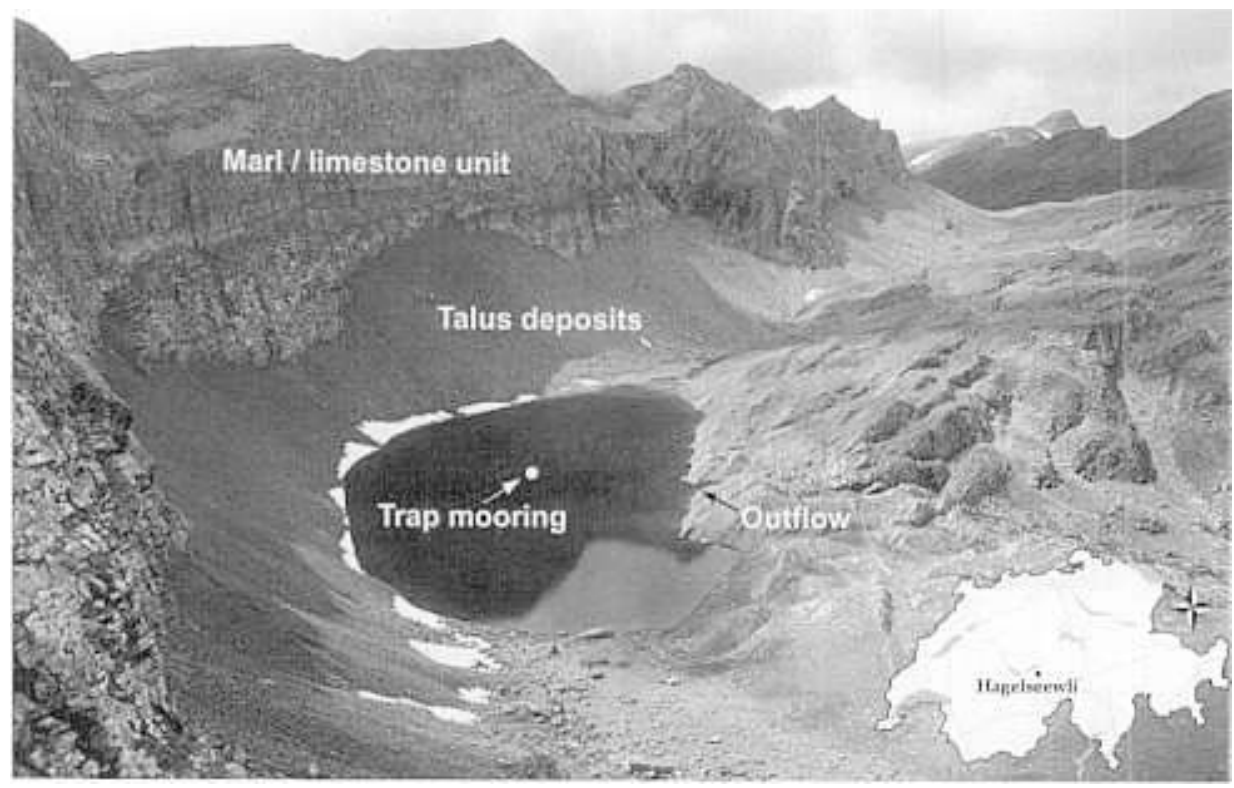

FIGURE 1. Photograph of Hagelseewli and its catchment showing the high cliff face to the south which is covered with debris cone deposits. View from the northeast. The location of Hagelseewli is indicated on the inset map of Switzerland.

\section{Measurements and Methods}

\section{MEASUREMENTS}

At Hagelseewli meteorological data (measured every 10 $\mathrm{min}$ ) and lake water temperatures (measured every $30 \mathrm{~min}$ ) were recorded automatically during $28 \mathrm{mo}$. Information on the presence or absence of ice on the lake was noted during each sampling. Lake water chemsitry and plankton composition were determined at biweekly to monthly intervals during the ice-free

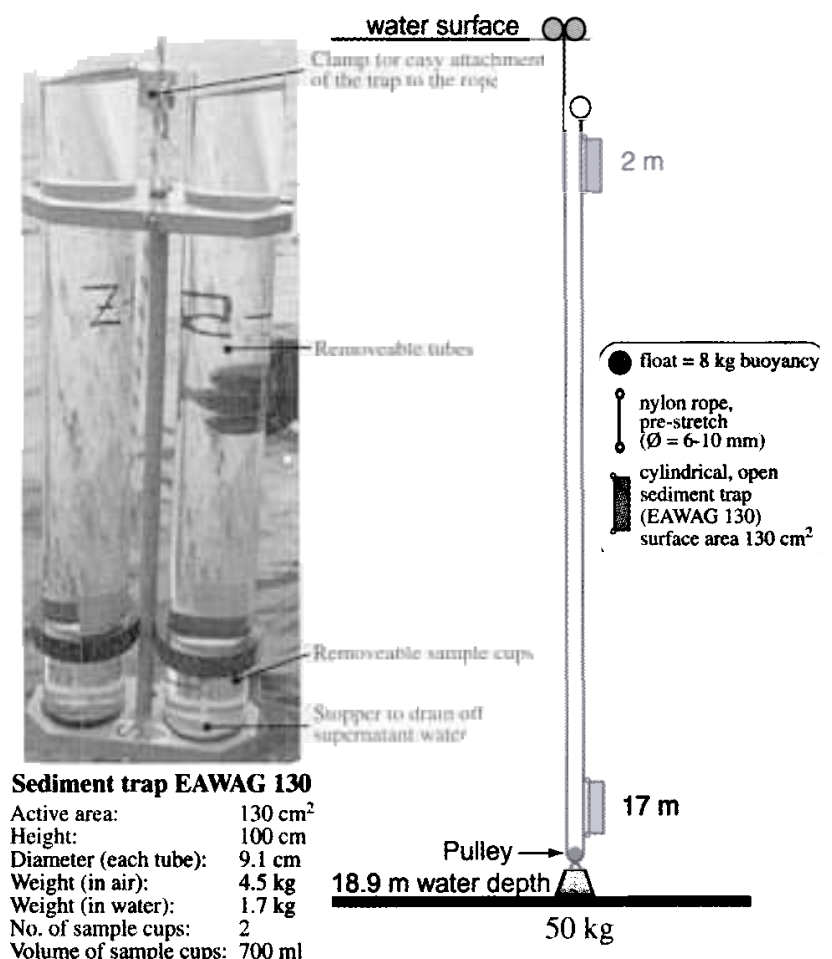

FIGURE 2. Sketch of the trap mooring in Hagelseewli (modified from Goudsmit et al., 2000) and photograph of an EAWAG 130 trap. Two traps were moored to a nylon rope that was turned back by a pulley at the lake bottom in order to avoid sediment resuspension during trap exchanges. season, and at bimonthly intervals during the period of ice cover. An analysis of all chemical, physical, and biological water column data is presented in Ohlendorf et al. (2000). For the purpose of this paper temperature, $\mathrm{pH}$, alkalinity, conductivity and calcium values, determined following standard procedures (DEW, $1996)$, were used to calculate calcite saturation indicees $(\Omega)$.

To assess the total sediment flux as well as the seasonal variability in the composition of particles in the water column two moored, open sediment traps (EAWAG-130) were installed at 2 and $17 \mathrm{~m}$ water depth (Fig. 2). The sediment traps consist of 2 PVC-tubes with an inner diameter of $91 \mathrm{~mm}$, a length of $1.0 \mathrm{~m}$, and an active area of $130 \mathrm{~cm}^{2}$. The sediment accumulates in two removable sample cups that have a volume of $700 \mathrm{ml}$ each and are equipped with four stoppers at different levels to allow the drainage of supernatant water (Fig. 2). Each trap is attached to a mooring string with a clamp at the top and a snap hook at the bottom to ensure an upright position. In total 10 samples were collected during both the ice-free and ice-covered periods between June 1996 and September 1998. Due to the long ice cover, the exposure times were very different ranging from $11 \mathrm{~d}$ under ice-free conditions to $313 \mathrm{~d}$ under ice-cover.

Several sediment cores were taken with a $63-\mathrm{mm}$-diameter gravity corer. The uppermost $37 \mathrm{~cm}$ of sediment were sub-sampled at 5-mm intervals to provide an average sample resolution of 5-10 yr (for details see Lotter et al., 2000).

Freeze dried sediment was investigated under the SEM (Philips XL 30) and analyzed for inorganic carbon with a coulometer (Coulometric Inc. $5011 \mathrm{CO}_{2}$-Coulometer). Total carbon and total sulfur were determined with a Carlo Erba CHNS Elemental Analyzer (Model EA 1108).

\section{CALCULATION OF CALCITE SATURATION}

In Hagelseewli the molar ratios of $\mathrm{Mg}$ : $\mathrm{Ca}$ range between 0.06 and 0.16 favoring the formation of pure calcite rather that Mg-calcite (Müller et al., 1972). Therefore for all water samples taken in Hagelseewli $\mathrm{CaCO}_{3}$ saturation indices $(\Omega)$ were computed following Berner (1971):

$$
\Omega=\frac{I A P}{K_{c}}
$$



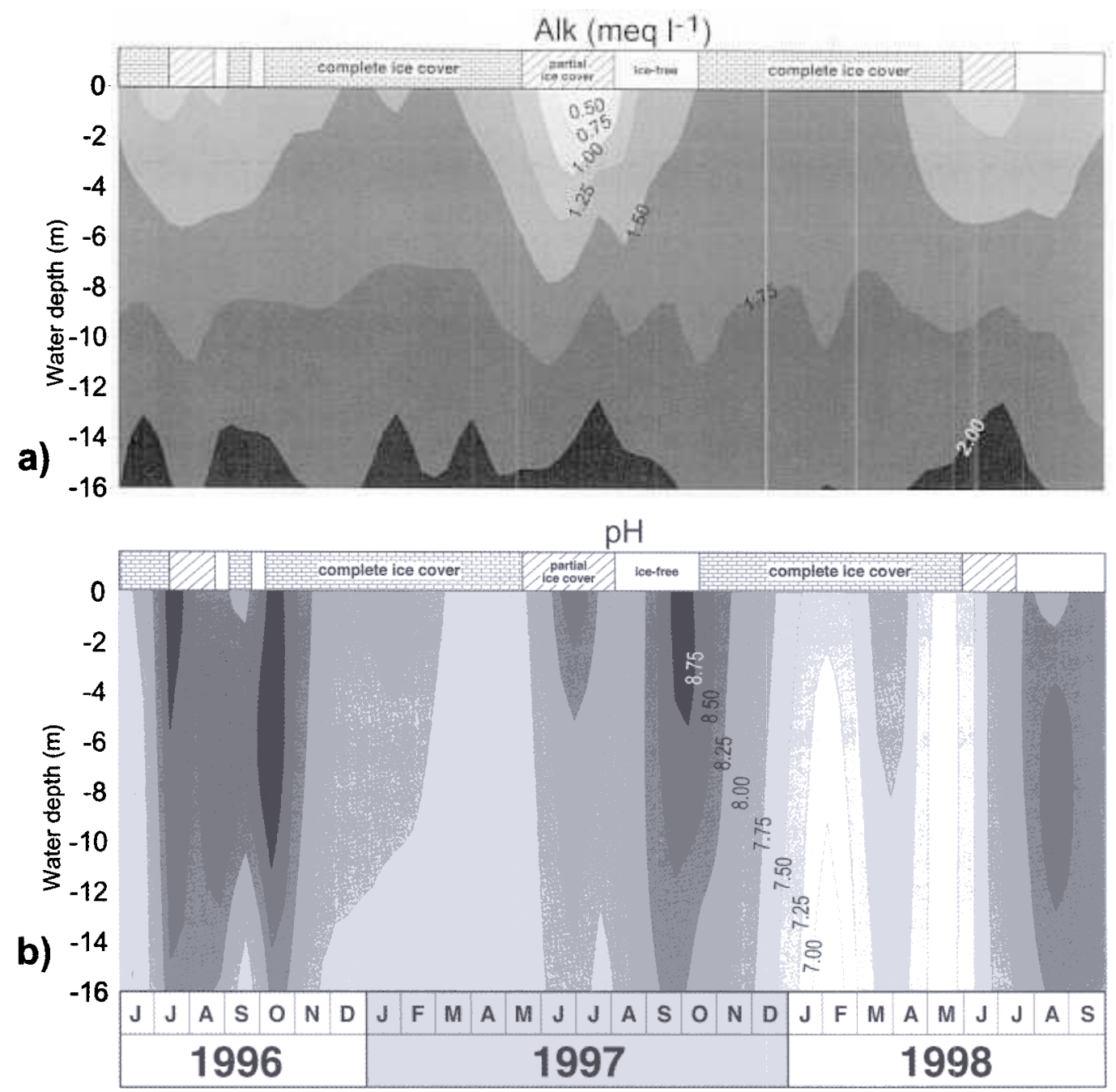

FIGURE 3. Chemical measurements made in the water column of Hagelseewli shown in relation to the ice cover status. Contour plots of (a) Alkalinity, Alk. (meq $\left.L^{-1}\right)$ and (b) $p H$ are shown. Measured values that were used for the calculation of countour lines are indicated by crosses.

where, $K_{c}$ is the equilibrium constant of $\mathrm{CaCO}_{3}$ at a given temperature. The ion activity product $(I A P)$ for $\mathrm{CaCO}_{3}$ was calculated from calcium concentrations, alkalinity, $\mathrm{pH}$, conductivity, and temperature with the set of equations and the equilibrium constants given in Stumm and Morgan (1996). Because Hagelseewli water is a dilute solution (average concentration $=3.4$ $10^{-3} \mathrm{~mol} \mathrm{~L}^{-1}$ ) the formation of complex ion species is insignificant and activity coefficients $(\gamma)$ can be obtained from the Debeye-Hückel relation:

$$
\log \gamma=-\frac{A Z^{2} \sqrt{I}}{1+a_{i} B \sqrt{I}}
$$

where $A$ and $B$ are temperature dependent constants, $a i$ is the diameter, and $Z$ the valence of a given ion. The ionic strength (I) was calculated from the specific conductivity $\left(\chi_{20} \mu \mathrm{S} \mathrm{cm}{ }^{-1}\right)$ by the empirical relation given in Maier and Grohmann (1977):

$$
I=1.83 \cdot \chi_{20} \cdot 10^{-5} \text {. }
$$

Since water temperature variations in Hagelseewli are relatively small the effect of the temperature dependent constants $(A, B, K c$, and $K 3$ ) on is negligible.

\section{Results}

In Hagelseewli the profiles of alkalinity (Fig. 3a) and $\mathrm{Ca}$ (not shown) show a minimum in the surface water that develops at the beginning of ice break-up and persists until the beginning of freeze over (cf. Ohlendorf et al., 2000). Values as low as 0.1 meq $\mathrm{L}^{-1}$ for alkalinity and $1.3 \mathrm{mg} \mathrm{L}^{-1}$ for $\mathrm{Ca}$, result from the dilution of lake water with ion-poor meltwater from the lake ice cover and the snowcover in the catchment during spring and early summer. Such reduced concentrations are detected down to $6 \mathrm{~m}$, whereas below this depth all profiles show an increase of concentrations with depth that does not vary considerably through time. Highest values of $2.4 \mathrm{meq} \mathrm{L}^{-1}$ for alkalinity and $60 \mathrm{mg} \mathrm{L}^{-1}$ for $\mathrm{Ca}$ were detected in the bottom water.

In contrast $\mathrm{pH}$-profiles (Fig. 3b) exhibit short, distinct maxima during the time of ice-free conditions. Lake water $\mathrm{pH}$ ranges between 6.7 and 9.2. The maximum $\mathrm{pH}$ occurred between 6 and $9 \mathrm{~m}$ depth in summer 1996 and 1998, whereas in summer 1997 $\mathrm{pH}$ was highest in the surface waters. During the remaining time of the year $\mathrm{pH}$ ranges between 7 and 8 . Under ice cover the bottom water turns anoxic (cf. Ohlendorf et al., 2000, for $\mathrm{O}_{2-}$ profiles) and the $\mathrm{pH}$ might drop to values below 7.0, like in winter $1997 / 98$. 



FIGURE 4. Calcite saturation and sediment trap data of Hagelseewli shown in relation to the ice cover status. The plots show (a) Calcite saturation indices $(\Omega)$ calculated as described in the text and $(b)$ Total sediment flux in the lower $(17 \mathrm{~m})$ and the upper $(2 \mathrm{~m})$ trap $\left(\mathrm{mg} \mathrm{m}^{-2} \mathrm{~d}^{-1}\right)$. In b) the occurrence of endogenic calcite crystals in the lower trap is indicated by pentagons. Numbers 4 a to $4 d$ refer to the SEM pictures shown in Figure 6.

The $\Omega$-values (Fig. 4a) show the same pattern as $\mathrm{pH}$, indicating that calcite saturation is mainly controlled by $\mathrm{pH}$ variations, as was also described by, e.g., Stabel (1986) for Lake Constance. Highest supersaturation in Hagelseewli generally occurs in late summer (end of August to mid-October) between 6 and $9 \mathrm{~m}$ water depth $\left(\Omega_{\text {mean }}=4.1\right.$, Figs. $\left.4 \mathrm{a}, 5\right)$. Supersaturation in the surface water is not particularly high $\left(\Omega_{\text {mean }}=1.7\right)$ at this time, due to the dilution by meltwater. In September and October 1996 the water at 6 and $9 \mathrm{~m}$ depth was more than 8.4 times supersaturated. In the latter case this happened under a thin cover of black ice (i.e. transparent ice). During ice break-up surface water is undersaturated whereas water below $6 \mathrm{~m}$ is slightly oversaturated with respect to calcite (Fig. 5). In contrast, during winter ice-cover the whole water column $\left(\Omega_{\text {mean }}=0.4\right)$, especially the bottom water, is strongly undersaturated (Fig. 5). $\Omega$ values as low as 0.03 were determined at $16 \mathrm{~m}$ water depth.

From the sediment trap material mean total fluxes of particles to the sediments were calculated (Fig. 4b). The flux of dry matter in the lower trap of $15 \mathrm{mg} \mathrm{cm}^{-2} \mathrm{yr}^{-1}$ is $25 \%$ higher than the mean sediment accumulation rate of $11 \mathrm{mg} \mathrm{cm}^{-2} \mathrm{yr}^{-1}$ based on ${ }^{137} \mathrm{Cs}$-dated sediment cores (Lotter et al., 2000). High accu- mulation rates during the long ice-covered periods are probably an artefact of the long exposure time that also included parts of the break-up and/or ice-free period. The trap material during these periods is composed of detrital minerals and amorphous organic matter that was washed into the lake with meltwaters during the time of ice break-up (Fig. 6a). Traps which were exposed during the ice-free periods show low particle fluxes (Fig. 4b) which mainly consist of chrysophyte cysts, centric and some pennate diatoms (Fig. 6b, 6c). When traps were changed in 14-d intervals during the ice-free period in summer 1996 and 1998 small differences in particle fluxes could be detected. Short intervals with slightly higher fluxes do occur during which planktonic diatoms (Lotter and Bigler, 2000; Ohlendorf et al., 2000), chrysophyte cysts and authigenic calcite precipitates of up to $30 \mu \mathrm{m}$ in diameter (Fig. 6b) were found in the lower trap (17 $\mathrm{m}$ water depth). However, calcite precipitates were never detected in the upper traps ( $2 \mathrm{~m}$ water depth).

Recent sediment accumulation rates in Hagelseewli are extremely low (11 $\mathrm{mg} \mathrm{cm}^{-2} \mathrm{yr}^{-1}$ ), but might have been higher in the past (Lotter et al., 2000). The sediments which were accumulated during the past $\sim 150 \mathrm{yr}$ have a very high content of 


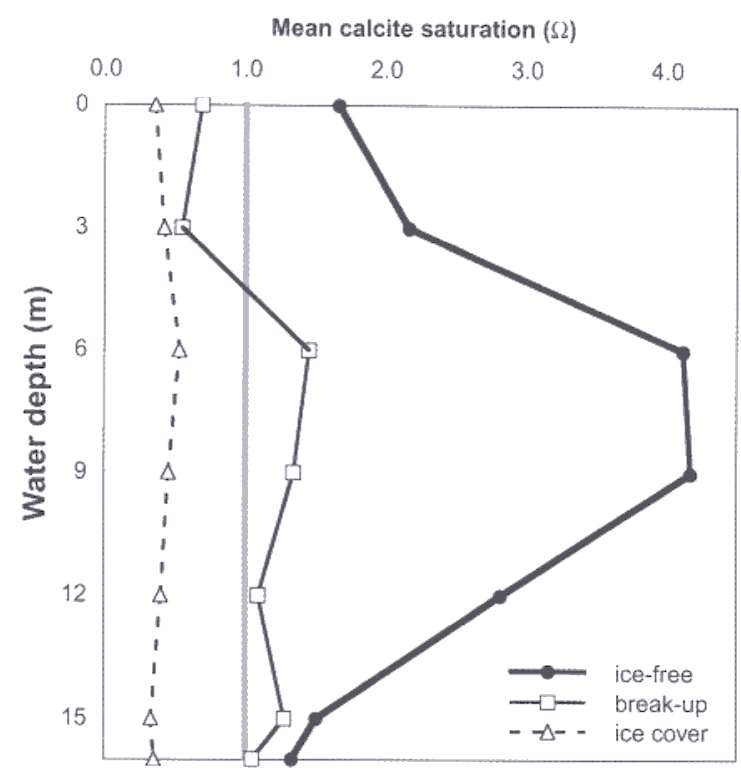

FIGURE 5. Mean calcite saturation indices $(\Omega)$ calculated for different seasons of the year. Note the occurrence of highest supersaturation $(\Omega>4.0)$ between 6 and $9 m$ water depth during the ice-free period in late summer.

organic matter (Fig. 7b and Lotter et al., 2000) and contain virtually no carbonate (Fig. 7 a) i.e. $0.27 \%$ on average. Between 0 and $2.5 \mathrm{~cm}$ sediment depth increased total carbon and sulfur concentrations were measured that reach up to 16 and $5.8 \%$, respectively (Fig. $7 \mathrm{c}$ ).

\section{Discussion}

Since Hagelseewli catchment rocks contain between 14 and $40 \%$ calcium carbonate it is not surprising that its water chemistry is comparable to typical hardwater lakes on the Swiss plateau (Table 1). In view of this it is expected that, similar to these lakes, biogenically induced calcite precipitation should occur in Hagelseeewli surface waters during times of high productivity. Theoretically precipitation of calcite can occur when the IAP of calcium and carbonate is greater than the equilibrium constant $\left(\mathrm{K}_{\mathrm{c}}\right.$ ), i.e., $\Omega$ is greater than 1.0 . However, in the epilimnion of hardwater lakes in temperate regions usually high supersaturations occur (Table 1) due to surface water warming (Hodell et al., 1998), intense photosynthesis and the presence of ions, mainly orthophosphate, that inhibit crystal growth (e.g., Kelts and Hsü, 1978; Stabel, 1986; House, 1987; Raidt and Koschel, 1988). Calcite precipitation usually occurs in the surface waters of a lake (Table 1), where supersaturation is highest, but not until the main inhibitor, orthophosphate, is totally depleted by phytoplankton blooms.

Different from the common pattern outlined above, supersaturation in Hagelseewli is highest between 6 and $9 \mathrm{~m}$ water depth but not at the surface (Table 1, Figs. 4a, 5). The reason for this peculiarity is that orthophosphate, which is limiting phytoplankton growth, reaches the lake water by redissolution from the sediment during ice cover and break-up and not by allochthonous input (Ohlendorf et al., 2000). Due to the high transparency of Hagelseewli water (Secchi depth $>7 \mathrm{~m}$ ), primary production (photosynthetic $\mathrm{CO}_{2}$ uptake) starts after complete ice break-up i.e. as soon as light is available at 6- to $9-\mathrm{m}$ water depth where phosphate concentrations are high. During this short time and depth interval there is one intense phytoplankton blonm as is reflected in high pH (Fig. 3b) and $\mathrm{O}_{2}$ values (Ohlendorf et al., 2000). Apparently all phosphate that was released from the sediments during winter, is consumed probably within less than $14 \mathrm{~d}$ (cf. Ohlendorf et al., 2000 for phosphate and chlorophyll$a$ measurements). Calcite supersaturation is resticted to this very short productivity pulse in late summer, where calcite precipitates in $4^{\circ} \mathrm{C}$ water as evidenced by sediment trap data (Fig. $6 \mathrm{~b}$, 6c). Calcite crystals of up to $30 \mu \mathrm{m}$ (Fig. 6b, 6c) were observed in the lower ( $17 \mathrm{~m}$ water depth) sediment trap from 28 August17 September 1996 and 26 July-6 August 1998, but never in the upper trap. Obviously the reduction of $\mathrm{CaCO}_{3}$ solubility due to increased water temperature does not play an important role in Hagelseewli. Calcite precipitation in this lake hence is only controlled by $\mathrm{pH}$ increase in response to enhanced photosynthetic $\mathrm{CO}_{2}$ uptake which is also unrelated to higher temperatures. The latter is in contrast to other studies where high productivity is caused by high water temperatures (Hodell et al., 1998). Thompson et al. (1997) report that highest calcite abundances during whiting events in Fayetteville Green Lake occur at $8 \mathrm{~m}$ water depth and are related to the photosynthetic activity of cyanobacterial picoplancton, namely Synechococcus. Considering this, it seems likely that, calcite precipitation in Hagelseewli is related to the occurrence of picoplankton too, which was not analyzed in this study.

The hypothesis of a single short precipitation pulse is also supported by the fact that not all sediment trap samples contain calcite crystals. In addition calcite crystals that were collected in the lower traps at different times of the open water period show distinct morphological features. Crystals collected at the beginning of the open water phase (Fig. 6b,c) show surface roughening, negative edges and/or enhanced columnar growth of one crystal face which indicates the adsorption of impurites (phosphate, organic compounds) to the crystal faces. These features are typically observed in eutrophic lakes with high supersaturation of calcite (Raidt and Koschel, 1988, 1993; Koschel, 1997). Crystals that were collected at the end of the open water period (Fig. 6d) show strongly rounded edges and corners-clear signs of dissolution. The bottom water below $12 \mathrm{~m}$ in this time interval was already undersaturated (Fig. 4b). This indicates that a significant portion of calcite probably is dissolved already very soon after it has been precipitated because, at the beginning of freeze over, phosphate that could inhibit dissolution (Berner and Morse, 1974) is not yet available in the bottom water (Ohlendorf et al., 2000).

As can be seen from Figure $4 b$, during most of the year Hagelseewli bottom water is undersaturated with respect to calcite. Due to incomplete turnover, bacterial respiration leads to bottom water anoxia during the extended period of ice cover (Ohlendorf et al., 2000). We observed an overgrowth of Chromatiaceans which live at the $\mathrm{H}_{2} \mathrm{~S} / \mathrm{O}_{2}$ interface and use light for the oxidation of $\mathrm{H}_{2} \mathrm{~S}$ to $\mathrm{SO}_{4}{ }^{2-}$ (Pfennig, 1967; Gorlenko and Kusnezow, 1972), on the lower trap during the first trap exchange after winter ice cover in summer 1998. This indicates that the $\mathrm{H}_{2} \mathrm{~S} / \mathrm{O}_{2}$ interface at that time must have been around $17 \mathrm{~m}$ water depth. Mineralization processes can lower the $\mathrm{pH}$ of hypolimnetic water to values below 7.0, which is favorable for the dissolution of calcite. In combination with very low sedimentation rates in the range of $0.6 \mathrm{~mm} \mathrm{yr}^{-1}$ (Lotter et al., 2000) this apparently leads to a complete dissolution of all calcite that was precipitated in the preceeding summer. Consequently, the sediments of Hagelseewli are free of carbonate (Fig. 7a), although it is a hardwater lake (Table 1). Instead, the topmost 2 to $3 \mathrm{~cm}$ of sediment contain increased amounts of organic matter and sulfur (Fig. 7h. c). This may be due to a better preservation of 

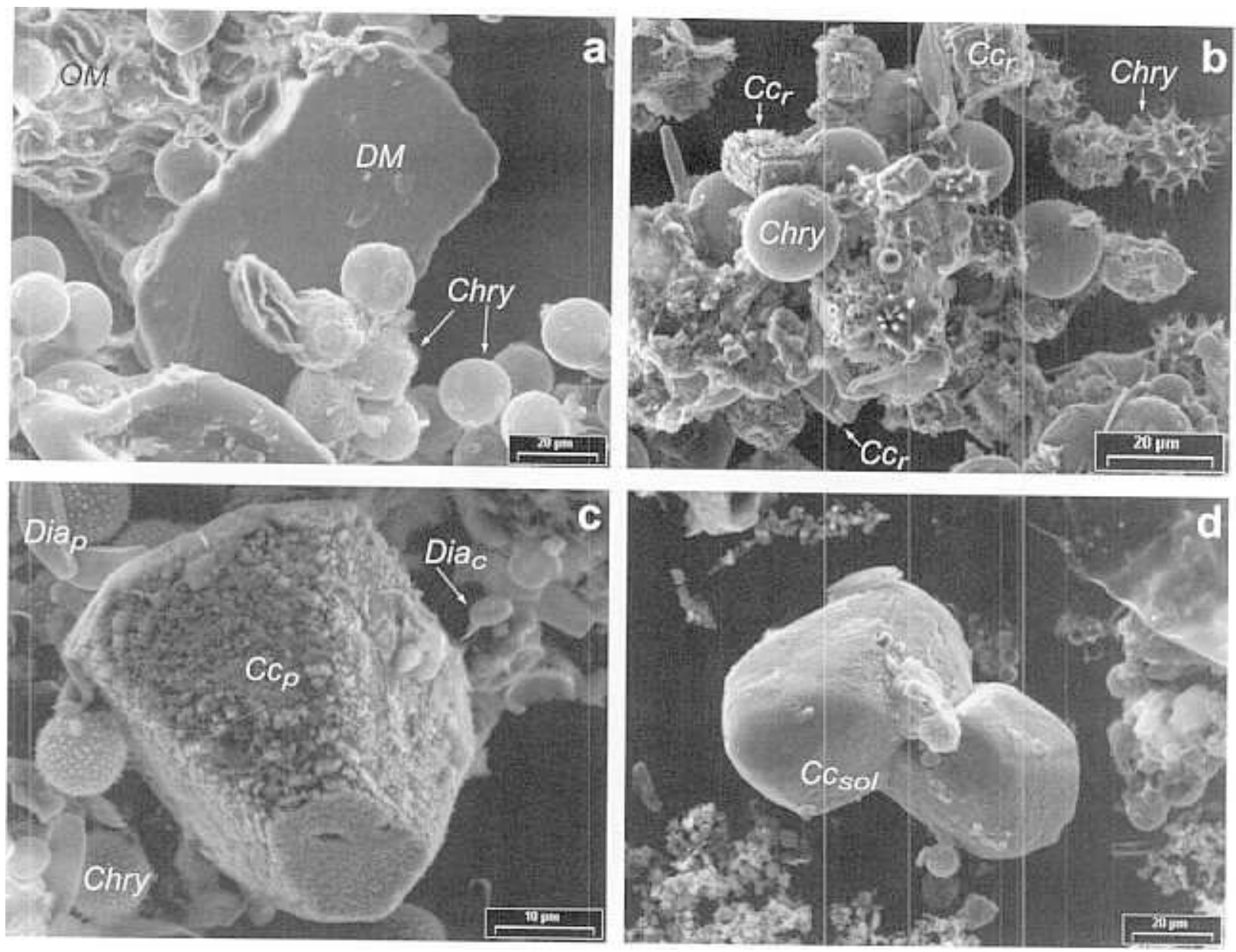

FIGURE 6. SEM pictures of Hagelseewli sediment trap material. (a) Lower $(17 \mathrm{~m})$ trap 11.06.9628.08.96: Detrital minerals (DM), amorphous organic matter (OM) and Chrysophycean cysts (Chry); (b) Lower $(17 \mathrm{~m})$ trap 26.07.98-06.08.98: Chry, pollen grains (Po) and small (10 $\mu \mathrm{m})$ rhombohedral calcite crystals (Ccr); (c) Lower $(17 \mathrm{~m}$ ) trap 28.08.96-17.09.96: Chry, pennate, periphytic diatoms (Diap), centric, planktonic diatoms (Diac) and large $(30 \mu \mathrm{m})$ pentagonal calcite crystals $(C c p)$ with rough surfacees; (d) Lower $(17 \mathrm{~m})$ trap 17.09.96-01.10.96: Pentagonal calcite crystals $(C \mathrm{cp})$ with rounded edges and smooth surface due to beginning dissolution.

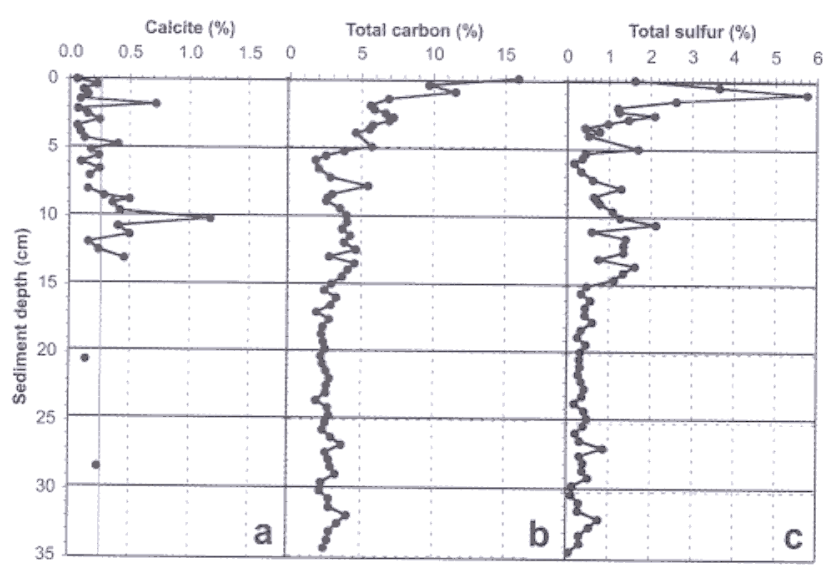

FIGURE 7. Sediment profiles of (a) calcite concentration (the gray line marks the mean of $0.3 \%$ ), (b) total carbon, and (c) total sulfur. The analysis were done on cores HAG 96/2 and HAG 96/3, see Lotter et al. (2000) for details. Note the signifcantly higher values for total carbon and total sulfur in the topmost four samples. these components with increasing anoxia during the last 30 to $40 \mathrm{yr}$.

One reason why calcite is preserved in the sediments of deeper hardwater lakes, like, for example, Baldeggersee but not in Hagelseewli, is that the amount of calcite that is precipitated in the course of a year is much higher. Hence calcite crystals are buried much faster which protects them from dissolution. For example, in Baldeggersee sediment calcite content is $>60 \%$ and total sediment accumulation rates are 10 times higher, $\sim 100$ $\mathrm{mg} \mathrm{cm}^{-2} \mathrm{yr}^{-1}$ (Lotter et al., 1997) than in Hagelseewli. Moreover, owing to their greater depth, undersaturation in these lakes may not be as severe in the bottom waters, where precipitated calcite is subject to dissolution. Instead it is highest in the zone of intense mineralization, i.e. between 10 and $20 \mathrm{~m}$ water depth (Table 1). Hence, calcite precipitates in Baldeggersee are in direct contact with strongly undersaturated water for a much shorter time.

Assuming that all calcite precipitates in Hagelseewli are contained in the average trap flux of $15 \mathrm{mg} \mathrm{cm}^{-2} \mathrm{yr}^{-1}$ but, due to complete dissolution, are not contained in the sediment accumulation rate of $11 \mathrm{mg} \mathrm{cm}^{-2} \mathrm{yr}^{-1}$, we hypothesize that $\mathrm{Ha}$ gelseewli sediments could contain $25 \%$ calcite if no dissolution would occur. This would amount to a calcite flux of $39 \mathrm{~g} \mathrm{CaCO}_{3}$ 
Long-term mean concentrations of $C a$ and $M g\left(m g L^{-1}\right)$, alkalinity (meq $\left.L^{-1}\right)$, conductivity $\left(\mu S \mathrm{~cm}^{-1}\right)$, and calcite saturation indices $\left(\Omega_{\min }\right.$ and $\left.\Omega_{\max }\right)$ in Hagelseewli compared to other lakes on the Swiss plateau with authigenic calcite precipitation. The water depths $\left(D_{\min }\right.$ and $D_{\max }$ in $m$ ) where maximum and minimum $\Omega$-values occur are also shown

\begin{tabular}{lcccccccc}
\hline \hline \multicolumn{1}{c}{ Lake } & $\mathrm{Ca}$ & $\mathrm{Mg}$ & Alkalinity & Conductivity & $\Omega_{\min }$ & $\mathrm{D}_{\min }$ & $\Omega_{\max }$ & $\mathbf{D}_{\mathbf{n}}$ \\
\hline Hagelseewli & 36 & 5 & & 187 & 0.03 & 16 & \\
Zürich & 46 & 6 & 220 & 0.35 & 130 & $\mathbf{6 - 9}$ \\
Baldegger See & 77 & - & 359 & 0.18 & 10 & $\mathbf{0 - 5}$ \\
Greifensee & 63 & 18 & & 449 & 0.77 & 20 & $\mathbf{0}$ \\
Lucerne & 50 & 8 & & 193 & 0.15 & 0 & $\mathbf{0 - 5}$ \\
Constance & 51 & 7 & & 281 & 0.94 & 50 & $\mathbf{0 - 5}$ \\
\hline
\end{tabular}

$\mathrm{m}^{-2} \mathrm{yr}^{-1}$. A comparable amount of calcite $\left(34 \mathrm{~g} \mathrm{CaCO}_{3} \mathrm{~m}^{-2} 14\right.$ $\mathrm{d}^{-1}$ ) is produced during one single spring precipitation event in Baldeggersee that only lasts for less than $14 \mathrm{~d}$ (Sturm et al., 1997). Therefore, we propose that the rate of calcite precipitation in Hagelseewli is similar to low-altitude temperate hardwater lakes. Due to the very short open water season and the limited amount of available orthophosphate only one calcite precipitation event occurs per year that is similar in magnitude to Baldeggersee.

\section{Conclusions}

The observation of high calcite supersaturation $(\Omega)$ between 6 and $9 \mathrm{~m}$ water depth together with the fact that large calcite precipitates were only found in the lower $(17 \mathrm{~m})$ sediment traps indicate that in contrast to most previously described lakes calcite precipitation in Hagelseewli occurs at greater depth in $4^{\circ} \mathrm{C}$ cold water. We hypothesize that this could be related to the activity of cyanobacterial picoplankton. However, calcite precipitation in Hagleseewli is similar in magnitude to a precipitation event in a low-altitude temperate, hardwater lake but, due to calcite dissolution in the bottom water, is not archived in the sediment record. The latter is a result of the mixing characteristics and the long period of ice coverage at Hagelseewli. For paleolimnologic studies this implies that the absence of biogenic calcite crystals in the sediments of a hardwater lake does not necessarily imply that no precipitation occurs in the lake.

However, in the case of Hagelseewli, it might be possible to use longer sedimentary records of this lake as an indictor of the calcite saturation status in the bottom water which is linked to the mixing of the lake and the length of ice coverage. Conditions that would be favorable for the preservation of calcite precipitates are complete turnover and thus bottom water oxygen replenishment in conjunction with higher sedimentation rates, e.g., as a result of higher calcite fluxes or higher allochthonous input. Such conditions should prevail in a warmer climate with wetter summer conditions, i.e., longer ice-free periods and more catchment erosion. It is, therefore, hypothesized that Hagelseewli sediments that were accumulated under such conditions, e.g., during the early and mid-Holocene climatic optimum, may contain calcite precipitates in larger quantities.

\section{Acknowledgments}

We gratefully acknowledge the assistance and advice of $\mathbf{M}$. Dittrich, G.-H. Goudsmit, E. Grieder, P. Inauen, A. Lammi, G. Lemcke, D. M. Livingstone, A. F. Lotter, V. Matta, C. Meile, B. Müller, M. Schurter, C. Stengel, R. Stierli, and A. Zwyssig in the field, in the laboratory, and during discussions of the results. We thank two anonymous reviewers for their critical comments that helped to improve the paper. This research was made possible by funding from the Swiss Federal Office of Education and Science (Grant No. 95.0518-1) within the framework of the European Union Environment and Climate project MOLAR (Measuring and Modelling the Dynamic Response of Remote Mountain Lake Ecosystems to Environmental Change: a Programme of Mountain Lake Research; Contract No. ENV4-CT95-007) and by the Swiss National Science Foundation within the framework of Priority Program Environment grant 5001-44600.

\section{References Cited}

Berner, R. A., 1971: Principles of Chemical Sedimentology. New York: McGraw-Hill Book Company. 240 pp.

Berner, R. A. and Morse, J. W., 1974: Dissolution kinetics of calcium carbonate in sea water: IV. Theory of caclite dissolution. American Journal of Science, 274(2): 108-134.

Brunskill, G. J., 1969: Fayetteville Green Lake, New York. II. Precipitation and sedimentation of calcite in a meromictic lake with laminated sediments. Limnology and Oceanography, 14: 830-847.

DEW, 1996: Deutsche Einheitsverfahren zur Wasseruntersuchung, Band II, VCH Weinheim, New York.

Gorlenko, W. M. and Kusnezow, S. I., 1972: Über die photosynthetisierenden Bakterien des Kononjer-Sees. Archiv für $\mathrm{Hy}$ drobiologie, 70(1): 1-13.

Goudsmit, G.-H., Lemcke, G., Livingstone, D. M., Lotter, A. F, Müller, B., and Sturm, M., 2000: Hagelseewli: a fascinating mountain lake-suitable for palæoclimate studies? Verhandlungen der Internationalen Vereinigung für Limnologie, 27(2): 1013-1022.

Hodell, D. A., Schelske, C. L., Fahnenstiel, G. L., and Robbins, L. L, 1998: Biologically induced calcite and its isotopic composition in Lake Ontario. Limnology and Oceanography, 43(2): $187-199$.

House, W. A., 1987: Inhibitation of calcite crystal growth by inorganic phosphate. Journal of Colloid and Interface Science, 119: 505-511.

Kelts, K. and Hsü, K. J., 1978: Freshwater Carbonate Sedimentation. In Lerman, A. (ed.), Lakes: Chemistry, Geology and Physics. New York: Springer, 295-323.

Koschel, R. H., 1997: Structure and function of pelagic caclite precipitation in lake ecosystems. Verhandlungen der Internationalen Vereinigung für Limnologie, 26: 343-349.

Kunz, B. and Stumm, W., 1984: Kinetik der Bildung und des Wachstums von Caciumcarbonat. Vom Wasser, 62: 279-293.

Livingstone, D. M., Lotter, A. F., and Walker, I. R., 1999: The decrease in summer surface water temperature with altitude in Swiss Alpine lakes: a comparison with air temperature lapse rates. Arctic, Antarctic, and Alpine Research, 31(4): 341-352.

Lotter, A. F. and Bigler, C., 2000: Do diatoms in the Swiss Alps reflect the length of ice-cover? Aquatic Sciences, 62(2): 125 141.

Lotter, A. F., Sturm, M., Teranes, J. L., and Wehrli, B., 1997: 
Varve formation since 1885 and high-resolution varve analysis in hypertrophic Baldeggersee, Switzerland. Aquatic Sciences, 59: 304-325.

Lotter, A. F., Appleby, P., Hofmann; W., Kamenik, C., Ohlendorf, C., Sturm, M., van der Kaap, P., and van Leeuwen, J., 2000: Sediment analysis of Hagelseewli $2339 \mathrm{~m}$ a.s.l. in the Swiss Alps. Journal of Limnology, 59(Suppl 1): 53-64.

Maier, D. and Grohmann, A., 1977: Bestimmung der Ionenstärke natürlicher Wässer aud deren elektrischer Leitfähigkeit. Journal for Water and Wastewater Research, 10(1): 9-12.

Minder, L., 1922: Über biogene Entkalkung im Zürichsee. Verhandlungen der Internationalen Vereinigung für Limnologie, 1: 20-32.

Müller, G., 1966: Die Sedimentbildung im Bodensee. Naturwissenschaften, 53: 237-247.

Müller, G., Irion, G., and Foerstner, U., 1972: Formation and diagenisis of inorganic Ca- $\mathrm{Mg}$ carbonates in the lacustrine environment. Naturwissenschaften, 59(4): 158-164.

Ohlendorf, C., Bigler, C., Goudsmit G.-H., Lemcke, G., Livingstone, D. M, Lotter, A. F, Müller, B., and Sturm, M., 2000: Causes and effects of long ice cover on a remote high Alpine lake. Journal of Limnology, 59(Suppl. 1): 65-80.

Pfennig, N., 1967: Photosynthetic Bacteria. Annual Reviews of Microbiology, 21: 285-324.
Raidt, H. and Koschel, R., 1988: Morphology of calcite crystals in hardwater lakes. Limnologica, 19(2): 3-12.

Raidt, H. and Koschel, R., 1993: Variable morphology of calcite crystals in hardwater lakes. Limnologica, 23(1): 85-89.

Stabel, H.-H., 1986: Calcite precipitation in Lake Constance: Chemical equilibrium, sedimentation and nucleation by algae. Limnology and Oceanography, 31(5): 1081-1093.

Strong, A. E. and Eadie, B. J., 1978: Satellite observations of calcium carbonate precipitations in the Great Lakes. Limnology and Oceanography, 23(5): 877-887.

Stumm, W. and Morgan, J., 1996: Aquatic Chemistry: Chemical Equilibria and Rates in Natural Waters. New York: Wiley, $1022 \mathrm{pp}$.

Sturm, M., Friedel, G., Lotter, A. F., Inauen, P., Stengel, C., and Zwyssig, A., 1997: Results of high resolution sediment traps proof model of varve formation in Baldeggersee, Switzerland. Würzburger Geographische Manuskripte, 41: 211.

Sturm, M., Zeh, U., Müller, J., Sigg, L., and Stabel, H-H., 1982: Schwebstoffuntersuchungen im Bodensee mit Intervall-Sedimentationsfallen. Eclogae Geologicae Helvetiae, 75(3): 579588.

Thompson, J. B., Schultze-Lam, S., Beveridge, T. J., and Des Marais, J. D., 1997: Whiting events: Biogenic origin due to the photosynthetic activity of cyanobacterial picoplankton. Limnology and Oceanography, 42(1): 133-141. 